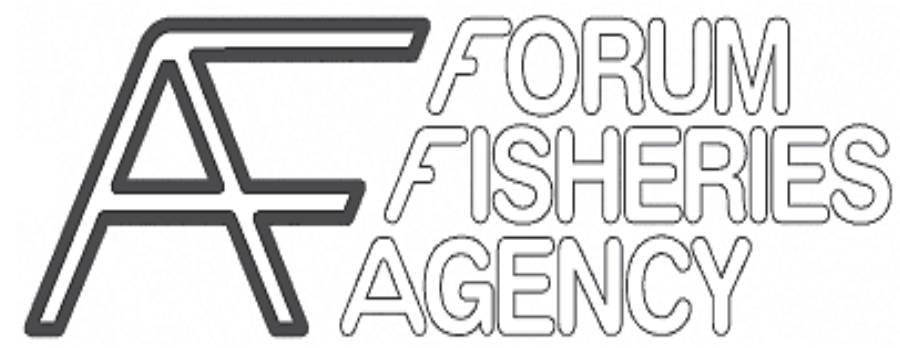

South Pacific Forum Fisheries Agnecy

Convention

FFA Report 79/02

PACIFIC ISLANDS FORUM FISHERIES AGENCY

P.O.BOX 629 HONIARA SOLOMON ISLANDS

TELEPHONE (677) 21124

FAX (677) 23995

WEB http://www.ffa.int 


\section{SOUTH PACIFIC FORUM FISHERIES AGENCY CONVENTION}

\section{THE GOVERNMENTS COMPRISING THE SOUTH PACIFIC FORUM}

Noting the Declaration on Law of the Sea and a Regional Fisheries Agency adopted at the 8th South Pacific Forum held in Port Moresby in August 1977;

Recognising their common interest in the conservation and optimum utilisation of the living marine resources of the South Pacific region and in particular of the highly migratory species;

Desiring to promote regional co-operation and co-ordination in respect of fisheries policies;

Bearing in mind recent developments in the law of the sea;

Concerned to secure the maximum benefits from the living marine resources of the region for their peoples and for the region as a whole and in particular the developing countries; and

Desiring to facilitate the collection, analysis, evaluation and dissemination of relevant statistical scientific and economic information about the living marine resources of the region, and in particular the highly migratory species;

HAVE AGREED AS FOLLOWS:

ARTICLE I

AGENCY

1. There is hereby established a South Pacific Forum Fisheries Agency.

2. The Agency shall consist of a Forum Fisheries Committee and a Secretariat.

3. The seat of the Agency shall be at Honiara, Solomon Islands.

\section{ARTICLE II \\ MEMBERSHIP}

Membership of the Agency shall be open to:

(a) members of the South Pacific Forum

(b) other states or territories in the region on the recommendation of the Committee and with the approval of the Forum.

ARTICLE III

\section{RECOGNITION OF COASTAL STATES' RIGHTS}

1. The Parties to this Convention recognise that the coastal state has sovereign rights, for the purpose of exploring and exploiting, conserving and managing the living marine resources, including highly migratory species, within its exclusive economic zone or fishing zone which may extend 200 nautical miles from the baseline from which the breadth of its territorial sea is measured. 
2. Without prejudice to Paragraph (1) of this Article the Parties recognise that effective co-operation for the conservation and optimum utilisation of the highly migratory species of the region will require the establishment of additional international machinery to provide for co-operation between all coastal states in the region and all states involved in the harvesting of such resources.

\section{ARTICLE IV \\ COMMITTEE}

1. The Committee shall hold a regular session at least once every year. A special session shall be held at any time at the request of at least four Parties. The Committee shall endeavour to take decisions by consensus.

2. Where consensus is not possible each Party shall have one vote and decisions shall be taken by a two-thirds majority of the Parties present and voting.

3. The Committee shall adopt such rules of procedure and other internal administrative regulations as it considers necessary.

4. The committee may establish such sub-committees, including technical and budget sub-committees as it may consider necessary.

5. The South Pacific Bureau for Economic Co-operation (SPEC) may participate in the work of the Committee. States, territories and other international organisations may participate as observers in accordance with such criteria as the Committee may determine.

\section{ARTICLE V \\ FUNCTIONS OF THE COMMITTEE}

1. The functions of the Committee shall be as follows:

(a) to provide detailed policy and administrative guidance and direction to the Agency;

(b) to provide a forum for Parties to consult together on matters of common concern in the field of fisheries;

(c) to carry out such other functions as may be necessary to give effect to this Convention.

2. In particular the Committee shall promote intra-regional co-ordination and cooperation in the following field:

(a) harmonisation of policies with respect to fisheries management;

(b) co-operation in respect of relations with distant water fishing countries;

(c) co-operation in surveillance and enforcement;

(d) co-operation in respect of onshore fish processing; 
(e) co-operation in marketing;

(f) co-operation in respect of access to the 200 mile zones of other Parties.

\section{ARTICLE VI}

\section{DIRECTOR, STAFF AND BUDGET}

1. The Committee shall appoint a Director of the Agency on such conditions as it may determine.

2. The Committee may appoint a Deputy Director of the Agency on such conditions as it may determine.

3. The Director may appoint other staff in accordance with such rules and on such conditions as the Committee may determine.

4. The Director shall submit to the Committee for approval:

(a) an annual report on the activities of the Agency for the preceding year;

(b) a draft work programme and budget for the succeeding year.

5. The approved report, budget and work programme shall be submitted to the Forum.

6. The budget shall be financed by contributions according to the shares set out in the Annex to this Convention. The Annex shall be subject to review from time to time by the Committee.

7. The Committee shall adopt financial regulations for the administration of the finances of the Agency. Such regulations may authorise the Agency to accept contributions from private or public sources.

8. All questions concerning the budget of the Agency, including contributions to the budget, shall be determined by the Committee.

9. In advance of the Committee's approval of the budget, the Agency shall be entitled to incur expenditure up to a limit not exceeding two-thirds of the preceding year's approved budgetary expenditure.

\section{ARTICLE VII \\ FUNCTIONS OF THE AGENCY}

Subject to direction by the Committee the Agency shall:

(a) collect, analyse, evaluate and disseminate to Parties relevant statistical and biological information with respect to the living marine resources of the region and in particular the highly migratory species;

(b) collect and disseminate to Parties relevant information concerning management procedures, legislation and agreements adopted by other countries both within and beyond the region; 
(c) collect and disseminate to Parties relevant information on prices, shipping, processing and marketing of fish and fish products;

(d) provide, on request, to any Party technical advice and information, assistance in the development of fisheries policies and negotiations, and assistance in the issue of licences, the collection of fees or in matters pertaining to surveillance and enforcement;

(e) seek to establish working arrangements with relevant regional and international organisations, particularly the South Pacific Commission; and

(f) undertake such other functions as the Committee may decide.

\section{ARTICLE VIII \\ LEGAL STATUS, PRIVILEGES AND IMMUNITIES}

1. The Agency shall have legal personality and in particular the capacity to contract, to acquire and dispose of movable and immovable property and to sue and be sued.

2. The Agency shall be immune from suit and other legal process and its premises, archives and property shall be inviolable.

3. Subject to approval by the Committee the Agency shall promptly conclude an agreement with the Government of Solomon Islands providing for such privileges and immunities as may be necessary for the proper discharge of the functions of the Agency.

\section{ARTICLE IX \\ INFORMATION} including:

The Parties shall provide the Agency with available and appropriate information

(a) catch and effort statistics in respect of fishing operations in waters under their jurisdiction or conducted by vessels under their jurisdiction;

(b) relevant laws, regulations and international agreements;

(c) relevant biological and statistical data; and

(d) action with respect to decisions taken by the Committee.

\section{SIGNATURE, ACCESSION, ENTRY INTO FORCE}

1. This Convention shall be open for signature by members of the South Pacific Forum.

2. This Convention is not subject to ratification and shall enter into force 30 days following the eighth signature. Thereafter it shall enter into force for any signing or acceding state thirty days after signature or the receipt by the depositary of an instrument of accession. 
3. This Convention shall be deposited with the Government of Solomon Islands (herein referred to as the depositary) who shall be responsible for its registration with the United Nations.

4. States or territories admitted to membership of the Agency in accordance with Article II(b) shall deposit an instrument of accession with the depositary.

5. Reservations to this Convention shall not be permitted.

\section{ARTICLE XI \\ WITHDRAWAL AND AMENDMENT}

1. Any Party may withdraw from this Convention by giving written notice to the depositary. Withdrawal shall take effect one year after receipt of such notice.

2. Any Party may propose amendments to the Convention for consideration by the Committee. The text of any amendment shall be adopted by a unanimous decision. The Committee may determine the procedures for the entry into force of amendments to this Convention.

IN WITNESS WHEREOF the undersigned, being duly authorised thereto by their respective Governments, have signed this Convention.

The FFA Convention was opened for signature at Honiara on 10 July 1979. The original parties to the FFA Convention were Australia, Cook Islands, Fiji, Kiribati, Nauru, New Zealand, Solomon Islands, Tonga, Tuvalu, and Western Samoa.

Papua New Guinea acceded to the Convention on 13 September 1979.

Niue acceded to the Convention on 18 October 1979.

Vanuatu acceded to the Convention on 9 March 1981.

Palau acceded to the Convention on 14 April 1986.

Marshall Islands acceded to the Convention on 27 March 1987. 


\begin{abstract}
ANNEX
As amended by the Twelfth Meeting of the Forum Fisheries

Committee, Suva, 4 - 8 May 1987
\end{abstract}

The following are the shares to be contributed by Parties to the Convention towards the budget of the Agency in accordance with Article VI(6) -

\begin{tabular}{lr} 
& $\begin{array}{c}\text { \% of core } \\
\text { budget }\end{array}$ \\
\hline Australia & 37.000 \\
Cook Islands & 1.176 \\
Federated States of Micronesia & 2.236 \\
Fiji & 2.236 \\
Kiribati & 1.176 \\
Marshall Islands & 2.236 \\
Nauru & 1.176 \\
New Zealand & 37.000 \\
Niue & 1.176 \\
Palau & 2.236 \\
Papua New Guinea & 2.236 \\
Solomon Islands & 2.236 \\
Tonga & 2.236 \\
Tuvalu & 1.176 \\
Vanuatu & 2.236 \\
Western Samoa & 2.236
\end{tabular}

Note: As detailed above, contributions are currently payable on three levels: Australia and New Zealand together contribute approximately $74 \%$ of the core budget. Federated States of Micronesia, Fiji, Marshall Islands, Palau, Papua New Guinea, Solomon Islands, Tonga, Vanuatu and Western Samoa together contribute approximately 20\% of the core budget and the small island States of Cook Islands, Kiribati, Nauru, Niue and Tuvalu together contribute approximately $6 \%$ of the core budget. 